\title{
Measurement of Soil-Gas Radon in Some Areas of Iraq Using Nuclear Track Detector CR-39
}

\author{
Khalid H. Abass, Baidaa Y. Mohammed, Azhar N. Rehem, Dalia J. Oleiwi \\ Department of Physics, College of Education for Pure Sciences, University of Babylon, Iraq \\ kalidhanin@yahoo.com E-mail address:
}

\section{Keywords: Measurement; Soil-Gas Radon; Using Nuclear Track Detector CR-39}

\begin{abstract}
The health hazards of the radioactive gas radon on general public are well known. In order to understand the level and distribution of ${ }^{222} \mathrm{Rn}$ concentrations in soil-gas in Babil province, we have measured the radon gas concentration in soil samples of different areas in Babylon (Alwerdeiaa, Al-seiahy, Al-Thewrae, Al-muhendisen, Al-keliss, Nadeer) by using alpha-emitters registrations which are emitted from radon gas in nuclear track detector (CR-39).

The obtained results have shown that the highest average radon gas concentration in soil sample was found in Al-muhendisen and Al-werdeiaa samples, which was $\left(32.75 \mathrm{~Bq} / \mathrm{m}^{3}\right)$, while the lowest average radon gas concentration in soil samples was found in Nadeer sample, which was $\left(25.85 \mathrm{~Bq} / \mathrm{m}^{3}\right)$.

The present results show that the radon gas concentration in all soil samples is below the allowed limit from (International Commission of Radiation Protection) (ICRP) agency.
\end{abstract}

\section{INTRODUCTION}

Radon is a naturally occurring odorless, colourless, tasteless, inert gas which is imperceptible to our sense. It is produced continuously from the decay of naturally occurring radionuclide such as ${ }^{238} \mathrm{U},{ }^{235} \mathrm{U}$, ${ }^{232} \mathrm{Th}$. The isotope ${ }^{222} \mathrm{Rn}$, produced from the decay of ${ }^{238} \mathrm{U}$, is the main source (approximately 55\%) of the internal radiation exposure to human life ${ }^{[13]}$. Radon comes from the natural decay of Uranium that is found in nearly all soils. It typically moves up through the ground to the air above and into homes through cracks and other holes in the foundation. ${ }^{[1]}$ Since all building materials contain various amounts of mainly natural radionuclides of the Uranium $\left({ }^{238} \mathrm{U}\right)$ and Thorium $\left({ }^{232} \mathrm{Th}\right)$ series, and the radioactive isotope of potassium $\left({ }^{40} \mathrm{~K}\right)$, those radionuclides are sources of the external and the internal radiation exposures in dwellings. Radon (half life: $3.824 \mathrm{~d}$ ) is radioactive gas produced by the disintegration of ${ }^{226} \mathrm{Ra}$, which is a decay product of ${ }^{238} \mathrm{U}$. The inhalation of radioactive inert gases radon $\left({ }^{222} \mathrm{Rn}\right.$, a daughter product of $\left.{ }^{226} \mathrm{Ra}\right)$ and Thoron $\left({ }^{220} \mathrm{Rn}\right.$, a daughter product of ${ }^{224} \mathrm{Ra}$ ), and heir short-lived products may be deposited on respiratory tract tissues when inhaled. Subsequent alpha decays may damage cells near the deposition site, contributing to an increased risk of lung cancer, and in the same time it helps in the treatment of malignant tumors (medical applications of radon. ${ }^{[2-4]}$

Consequently, building material is considered to be the second main source of radon in our houses after soil. After radon generated from radium decay in the solid grains, it emanated to pore gases or fluids and then migrate a significant distance from the site of generation in rock, soil or building materials into the atmosphere before undergoing radioactive decay in an exhalation process. ${ }^{[2,5-6]}$

The exhalation rate provides a measure of the liberation of radon from inside a sample to outside the sample. Its value depends on emanation and on the concentration gradient between pore and ambient air. ${ }^{[2,9]}$

While the plastic detector CR-39 or LR-115 and Gamma Spectroscopy can used to estimate Radon concentration in soil. ${ }^{[8-9]}$

The aim of the present work is to determine the radon concentration in soil gas at a specific depth within the soil. To do this, CR-39 used to determine alpha emitters from radon gas. 


\section{EXPERIMENTAL PART}

The determination of the concentrations of alpha particles emitted from radon gas in soil samples were performed by using the nuclear track detector (CR-39) of thickness $(2 \mu \mathrm{m})$ and area of about $\left(1 \times 1 \mathrm{~cm}^{2}\right)$. The radon gas concentration in soil samples was obtained by using the sealedcup technique as shown in Fig. (1).

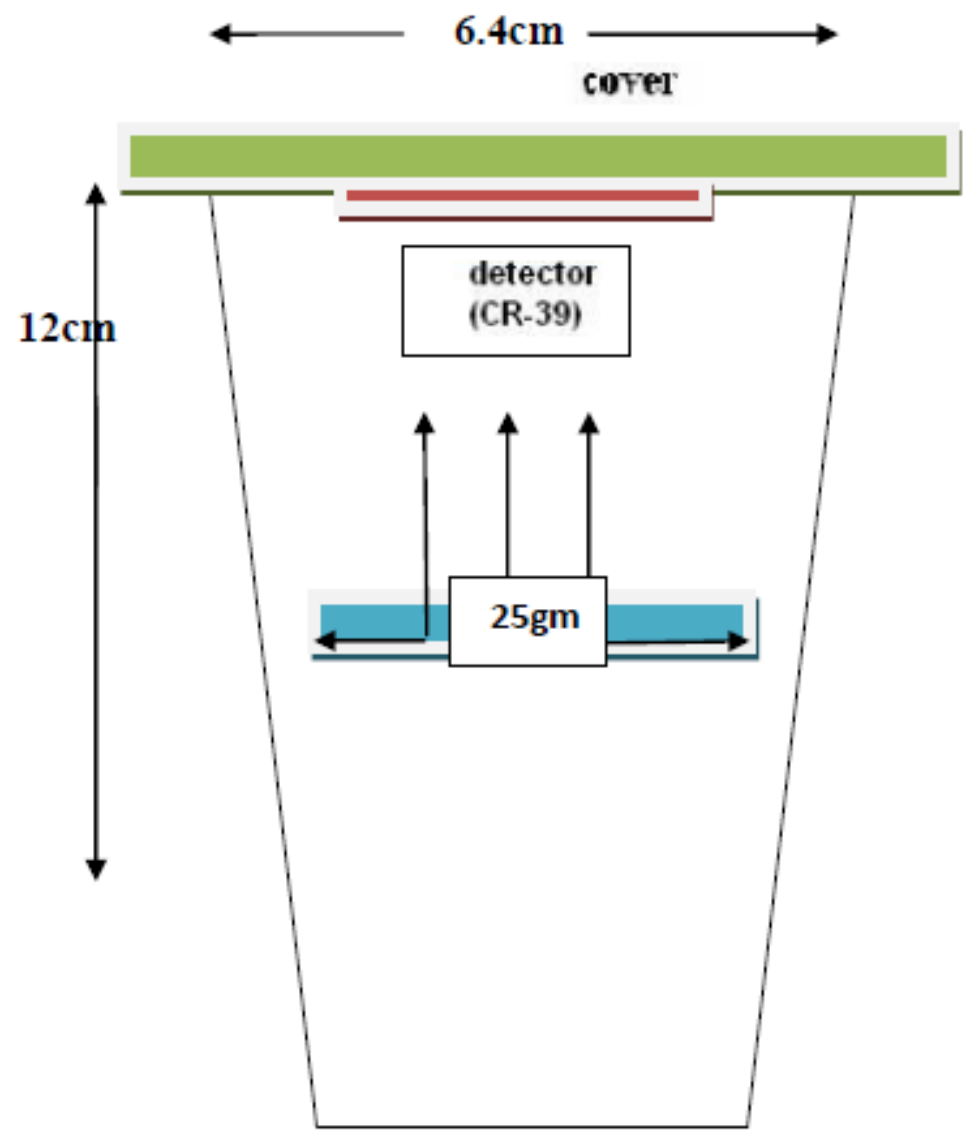

Fig. (1): A schematic diagram of the sealed-cup technique in soil sample.

After irradiation time (28 days), the CR-39 track detectors were etched in $6.25 \mathrm{~N}$ of $\mathrm{NaOH}$ solution at a temperature of $\left(70 \pm 1{ }^{\circ} \mathrm{C}\right)$ for $(5 \mathrm{hr})$, and the tracks density were recorded using an optical microscope with magnification $(400 \mathrm{X})$. The density of the tracks $(\rho)$ in the samples were calculated according to the following relation:

$$
\text { track density }(\rho)=\frac{\text { Average number of total pits (tracks) }}{\text { Area of field view }}
$$

The radon gas concentration in the soil samples were obtained by the comparison between track densities registered on the detectors of the samples and that of the standard soil samples which are shown in Fig.(2), using the relation [2]:

$$
\mathbf{C X}=\rho \mathbf{X} .(\mathbf{C S} / \rho \mathbf{S})
$$

Where :

$\mathrm{C}_{\mathrm{X}}$ : alpha particles concentration in the unknown sample.

$\mathrm{C}_{\mathrm{S}}$ : alpha particles concentration in the standard sample.

$\rho_{\mathrm{X}}$ : track density of the unknown sample $\left(\right.$ track $\left./ \mathrm{mm}^{2}\right)$.

$\rho_{\mathrm{S}}$ : track density of the standard sample $\left(\operatorname{track} / \mathrm{mm}^{2}\right)$. 


$$
\text { Slope }=\left(\rho_{S} / C_{S}\right)=0.145\left(\text { track } \cdot \mathrm{m}^{3} / \mathrm{mm}^{2} \cdot \mathrm{Bq}\right)
$$

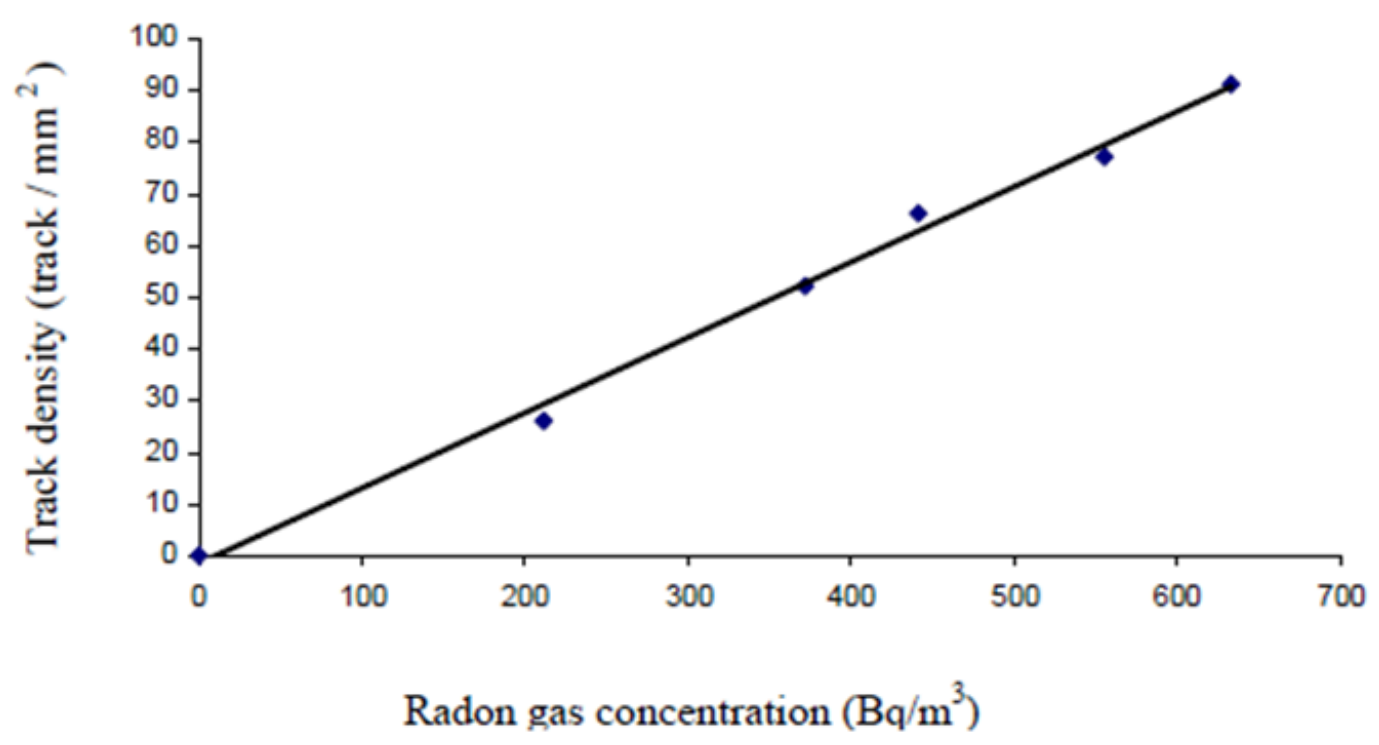

Fig. (2): Relation of radon gas concentration and track density in standard samples.

\section{RESULTS AND DISCUSSION}

To calculate the average value of radon for six different soil samples taken from different areas of the province of Babylon, and the extent of the radon gas concentration in these areas and found that the radon sample elected for AL-werdeiaa area $32.75 \mathrm{~Bq} / \mathrm{m}^{3}$. Effects recorded in the detector between density $(7-3)$ and density effects rate $\left(4.75\right.$ track. $\left.\mathrm{mm}^{-2}\right)$, and the concentration of radon to sample the Al-seiahy area of focus is the $(27.57 \mathrm{~Bq} / \mathrm{m})$ and density effects recorded in the detector ranging between (8-2) and the density rate effects (4 track.mm $\left.{ }^{-2}\right)$.

Scored gas radon concentration of a sample area of Al-Thewrae $\left(31.02 \mathrm{~Bq} / \mathrm{m}^{3}\right)$ the density effect recorded in the detector between (6-3) and the density effect rate (4.5 Track . $\mathrm{mm}^{-2}$ ). While radon recorded by the sample area Al-muhendisen focus was $\left(32.75 \mathrm{~Bq} / \mathrm{m}^{3}\right)$ and the intensity of the effects recorded in the detector (9-2) and density rate effects (4.75Track.mm $\left.{ }^{-2}\right)$. And the concentration of radon to sample the Al-keliss area of focus is the $(29.31 \mathrm{~Bq} / \mathrm{m})$ and density effects recorded in the detector ranging between $(6-2)$ and the density rate effects (4.25 Track. $\left.\mathrm{mm}^{-2}\right)$. Scored gas radon concentration of a sample Nadeer area $\left(25.85 \mathrm{~Bq} / \mathrm{m}^{3}\right)$ the density effect recorded in the detector between $(5-2)$ and the density effect rate $\left(3.75\right.$ track. $\left.\mathrm{mm}^{-2}\right)$. 


\begin{tabular}{|c|c|c|c|c|c|c|c|}
\hline \multirow[t]{2}{*}{ Sample code } & \multirow{2}{*}{$\begin{array}{c}\text { Out of the } \\
\text { sample }\end{array}$} & & \multicolumn{5}{|c|}{ Samples } \\
\hline & & & 1 & 2 & 3 & 4 & Mean \\
\hline \multirow{2}{*}{1} & \multirow[t]{2}{*}{ Al-werdeiaa } & $\begin{array}{l}\text { Density effects } \\
\quad\left(\text { Track.mm }{ }^{-2}\right)\end{array}$ & 5 & 7 & 3 & 4 & 4.75 \\
\hline & & $\begin{array}{c}\text { Radon } \\
\text { concentration } \\
\left(\mathrm{Bq} / \mathrm{m}^{3}\right) \\
\end{array}$ & 34.48 & 48.27 & 20.68 & 27.58 & 32.75 \\
\hline \multirow[b]{2}{*}{2} & \multirow[t]{2}{*}{ Al-seiahy } & $\begin{array}{l}\text { Density } \\
\text { effects } \\
\text { (Track.mm }{ }^{-2}\end{array}$ & 3 & 8 & 2 & 3 & 4 \\
\hline & & $\begin{array}{c}\text { Radon } \\
\text { concentration } \\
\left(\mathrm{Bq} / \mathrm{m}^{3}\right)\end{array}$ & 20.68 & 55.16 & 13.79 & 20.68 & 27.57 \\
\hline \multirow[t]{2}{*}{3} & \multirow[t]{2}{*}{ Al-Thewrae } & $\begin{array}{l}\text { Density } \\
\text { effects } \\
\text { (Track.mm² }\end{array}$ & 5 & 6 & 4 & 3 & 4.5 \\
\hline & & $\begin{array}{c}\text { Radon } \\
\text { concentration } \\
\left(\mathrm{Bq} / \mathrm{m}^{3}\right) \\
\end{array}$ & 34.48 & 41.37 & 27.58 & 20.68 & 31.02 \\
\hline \multirow[t]{2}{*}{4} & \multirow[t]{2}{*}{$\begin{array}{c}\text { Al- } \\
\text { muhendisen }\end{array}$} & $\begin{array}{l}\text { Density } \\
\text { effects } \\
\text { (Track.mm }{ }^{-2}\end{array}$ & 2 & 3 & 9 & 5 & 4.75 \\
\hline & & $\begin{array}{c}\text { Radon } \\
\text { concentration } \\
\left(\mathrm{Bq} / \mathrm{m}^{3}\right) \\
\end{array}$ & 13.39 & 20.68 & 62.06 & 34.48 & 32.75 \\
\hline \multirow[b]{2}{*}{5} & \multirow[t]{2}{*}{ Al-keliss } & $\begin{array}{l}\text { Density } \\
\text { effects } \\
\text { (Track.mm }^{-2}\end{array}$ & 5 & 2 & 4 & 6 & 4.25 \\
\hline & & $\begin{array}{c}\text { Radon } \\
\text { concentration } \\
\left(\mathrm{Bq} / \mathrm{m}^{3}\right) \\
\end{array}$ & 34.48 & 13.79 & 27.58 & 41.37 & 29.31 \\
\hline \multirow[t]{2}{*}{6} & \multirow[t]{2}{*}{ Nadeer } & $\begin{array}{l}\text { Density } \\
\text { effects } \\
\text { (Track.mm-2 }\end{array}$ & 5 & 4 & 4 & 2 & 3.75 \\
\hline & & $\begin{array}{c}\text { Radon } \\
\text { concentration } \\
\left(\mathrm{Bq} / \mathrm{m}^{3}\right) \\
\end{array}$ & 34.48 & 27.58 & 27.58 & 13.79 & 25.85 \\
\hline
\end{tabular}

\section{CONCLUSION}

From the present work, it can be concluded that the highest average radon gas concentration in soil samples was found in Al-werdeiaa and Al-muhendisen samples, which was $\left(32.75 \mathrm{~Bq} / \mathrm{m}^{3}\right)$, while the lowest average radon gas concentration in soil samples was found in Nadeer sample, which was $\left(25.85 \mathrm{~Bq} / \mathrm{m}^{3}\right)$. The present results show that the radon gas concentration in all soil samples, is below the allowed limit from ICRP agency (International Commission of Radiation Protection). 


\section{References}

[1] V. Duggal, A. Rani and R. Mehra, "Measurement of soil-gas radon in some areas of northern Rajasthan, India", J. Earth Syst. Sci., Vol. 123(6) pp. 1241-1247 (2014).

[2] N. M.Hassan, M. Hosoda, T. Ishikawa, S. Tokonami, M Fukushi, A. Hafez and E. Kkalil, " ${ }^{222} \mathrm{Rn}$ Exhalation Rate from Egyptian Building Materials Using Active and Passive Methods", Jpn. J. Health Phys., 44 (1), pp.106 -111, (2009).

[3] L. Bruzzi, R. Mele and F. Padoani, " Evaluation of gamma and alpha doses due to natural radioactivity of building materials", J. Radiol. Prot., Vol.12 (2), 67-76 (1992).

[4] S. Turhan, H. Yucel, L. Gunduz, S. Sahin, M. Vural, A. Paramksiz and B. Demircioglu, " Natural radioactivity measurement in pumice sample used raw materials in Turkey", Appl. Radiat. Isot., 65, 350 - 354 (2007).

[5] A. Bollofer, J. Storm, P. martin and S. Tims; "Geographic variability in radon exhalation at a rehabilitated uranium mine in the northern territory, Australia", Environ. Monit. Assess., 114, 313-330 (2006).

[6] S. D. Schary, M. H. Wilkening, K. P. Hart and S. D. Hill; "The flux of radon and thoron from Australian soils", J. Geophys. Res., 94, 8567 - 8576 (1989).

[7] S. Demartino, C. Sabbarese and G. Monetti, "Radon emanation and exhalation rates from soils measured with an electrostatic collector", Appl. Radiat. Isot., 49, 407-413 (1998).

[8] D. Mazur, M. Janik, J. Loskiewicz, p. Olko and J. Swakon, Radiation Measurment 13, pp. 295 300, (1999).

[9] J. Vaupotic, A. Gregoric, I Kobal, P. Zvab, K. Kozk, J. Mazur, E. Kochowska, and D.Grzaziel, "Natural Hazards and Earht System Science"s, 10, pp. 895-899, (2010).

[10] S. Singh, A. Kumar, B. Bajwa, S. Mahjan, V. Kumar and S. Dhar, , "Terr Atom Ocean", Vol. 21, No. 4, pp. 685-695, (2010).

[11] F. Bouzarjomohri and M. H. EhrampooshIran. J. Raiat. Res., 6(3), pp.141-144, (2008).

[12] A. K. Hasan, A .R. H. Subber and Ahmed R. Shaltakh, "Measurement of Radon Concentration in Soil Gas using RAD7 in the Environs of Al-Najaf Al-Ashraf City-Iraq", Pelagia Research Library, Advances in Applied Science Research, 2 (5), pp. 273-278, (2011).

[13] ICRP, Protection Against Radon-222 at Home and at Work. ICRP Publication 65. Ann. ICRP 23 (2), (1993). 